\title{
Does leptin play a cytokine-like role within the airways of COPD patients?
}

\author{
A. Bruno*, , P. Chanez\#, G. Chiappara*, L. Siena*, S. Giammanco`, M. Gjomarkaj*, \\ G. Bonsignore*, J. Bousquet ${ }^{\#}$ and A.M. Vignola ${ }^{\star}{ }^{\star}$
}

\begin{abstract}
The leptin-leptin receptor system might be up-regulated in the airways of chronic obstructive pulmonary disease (COPD). In bronchial biopsies obtained from normal subjects and smokers, with and without COPD, the present study examined leptin and leptin-receptor expression and their co-localisation in airway and inflammatory cells.

Combining immunohistochemistry with terminal deoxynucleotidyl transferase dUTP nick endlabelling techniques, apoptosis in airway and inflammatory cells and in leptin and leptin-receptor expressing cells was investigated. In the epithelial cells both leptin and leptin-receptor expression was higher in normal subjects than in smokers and COPD subjects. By contrast, in the submucosa, leptin was over-expressed in COPD when compared with normal subjects and smokers. Leptin and its receptor were co-localised, mainly with activated T cells (CD45R0) and CD8 ${ }^{+} \mathrm{T}$ lymphocytes.
\end{abstract}

In smokers, apoptosis was found in some inflammatory cells, whereas in COPD inflammatory cells, leptin and leptin-receptor positive cells were not apoptotic. Leptin expression was related to COPD severity and assessed using the Global initiative for Chronic Obstructive Lung Disease classification.

In conclusion, the present study shows an increased leptin expression in bronchial mucosa of chronic obstructive pulmonary disease patients, associated with airway inflammation and airflow obstruction.

\section{KEYWORDS: Chronic obstructive pulmonary disease, endobronchial biopsies, leptin}

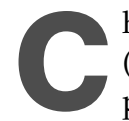

hronic obstructive pulmonary disease (COPD) is considered as a disease which profoundly affects a patient's quality of life. This burden is in part linked to inflammation and to structural changes of the respiratory tract, which are related to noxious particle exposure, including tobacco smoking. Persistent inflammation within the proximal airways is characterised by an endoluminal influx of neutrophils and the presence of activated lymphocytes and macrophages [1]. The recruitment and survival of those inflammatory cells within the airways might be linked to several mediators and growth factors including leptin. Leptin, the product of the $o b$ gene, is a pleiotropic molecule which regulates food intake and some metabolic and endocrine functions. Demonstrations have shown it to be secreted by adipose tissue [2], gastric mucosa [3], intestinal epithelial cells [4], placenta, mammary epithelium and skeletal muscle [5]. The leptinreceptor is expressed in peripheral tissues and cells, including: kidney, lung, adrenal gland, haematopoietic precursor cells and bone marrow, neutrophils, monocytes and peripheral T cells [6].
Leptin also plays a regulatory role in innate and acquired immunity, inflammation, and haematopoiesis [6]. Leptin shares similarities with some cytokines, including: interleukin (IL)-6, IL-11, ciliary neurotrophic factor and leukaemia inhibitory factor. Its receptor is homologous to the gp130 signal-transducing subunit of the IL-6-type cytokine receptors [7]. Leptin exerts proliferative and anti-apoptotic activities [8] in a variety of cell types, including: T lymphocytes, monocytes [9], and haematopoietic progenitors [10], leptin is also able to modulate the function of $\mathrm{T}$ lymphocytes and to polarise T helper (Th) cells towards a Th1 phenotype [6]. It is also able to modulate cell survival by inhibiting apoptosis [11] and affects cytokine production, the activation of monocytes / macrophages [12], wound healing [13], angiogenesis [14], and haematopoiesis. The signal transduction pathways regulated by leptin are diverse and include the characteristics of both cytokine and growth factor receptor signalling [15], indicating that leptin regulates important aspects of immunity by regulating both the number and the activation of T lymphocytes.
AFFILIATIONS

${ }^{*}$ Consiglio Nazionale delle Ricerche Istituto di Biomedicina e

Immunologia Molecolare-Sezione di Immunopatologia e Farmacologia

Clinica e Sperimentale dell'Apparato Respiratorio, Clinica Pneumologica Università di Palermo, and -Istituto di Fisiologia e Nutrizione Umana, Università di Palermo, Palermo, Italy.

\#Clinique des Maladies Respiratoires, University Hospital and INSERM U454, Hôpital Arnaud de Villeneuve, CHU Montpellier, France.

CORRESPONDENCE

A. Bruno

Istituto di Biomedicina e Immunologia Molecolare-Consiglio Nazionale delle Ricerche Via Ugo La Malfa 153-90146 Palermo Italy

Fax: 390916809122

E-mail: andreina@neomedia.it

Received:

August 052004

Accepted after revision:

April 262005

SUPPORT STATEMENT

The present study was supported by the Italian National Research CouncilCNR (Rome, Italy) and by a combined grant from INSERM-CNR (Paris, France).

$\dagger$ The present study is dedicated to the memory of A.M. Vignola.

European Respiratory Journal Print ISSN 0903-1936 Online ISSN 1399-3003 
Leptin production is acutely increased during infection and inflammation [7]. In some patients with COPD, plasmatic leptin levels are increased and this phenomenon is related to pro-inflammatory status and dietary intake [16]. Disturbances in leptin metabolism are related to energy imbalance during acute exacerbations of COPD [17]. COPD has been recognised as an inflammatory disease of the airways, however, it is increasingly being accepted that a link between airway and systemic inflammation may exist in COPD. Therefore, the current authors hypothesised that the leptin-leptin receptor system might be upregulated in the airway mucosa and that such a system may be involved in the regulation of the number and phenotype of $\mathrm{T}$ lymphocytes in the bronchial mucosa of COPD subjects. In smokers and COPD patients the Colocalisation of leptin and leptin-receptor expression with pertinent inflammatory cells was assessed [18]. The apoptotic status of inflammatory cells was also demonstrated and the cells that expressed leptin and leptin-receptors were detected. Finally, the present authors sought whether leptin and its receptor were associated with clinical and functional characteristics of COPD patients.

\section{MATERIALS AND METHODS \\ Patients}

COPD patients were selected according to Global initiative for Chronic Obstructive Lung Disease (GOLD) criteria [19]. In total, 15 current smokers with a normal lung function (GOLD stage 0$)$ were compared with 27 current smokers $(\geqslant 30$ pack $\cdot \mathrm{yrs}^{-1}$ ) with a mild-to-severe form of COPD (forced expiratory volume in one second (FEV1): $50-70 \%$ of predicted). All patients with COPD complained of various degrees of dyspnoea, with 15 reporting a chronic cough with sputum production. Eight smokers, with a normal lung function, reported chronic cough and sputum. The current authors enrolled 14 nonsmoking healthy volunteers as controls.

\section{Fibreoptic bronchoscopy}

Fibreoptic bronchoscopy was performed as previously described [20]. Between four to six bronchial biopsies were taken using the same forceps on a sub-segmental bronchus of the left, lower lobe. Bronchial specimens were processed as previously described in detail [20]. In brief, biopsies were fixed in $10 \%$ formaldehyde ( $\mathrm{pH} 7.2)$ and embedded in paraffin. Tissue sections, $4 \mu \mathrm{m}$ in size, were affixed to microscope slides which had been pre-treated with polylysine solution (Sigma Aldrich, St Louis, MO, USA). After de-waxing and rehydration the slides were used for immunohistochemistry. All biopsy samples were coded and sections were studied in a blinded fashion. Two independent pathologists made all evaluations, unaware of the biopsy code. The present study was approved by the ethic committee of Hôpital Arnaud de Villeneuve (Montpellier, France) and all patients agreed to participate by signing a written consent form.

\section{Enumeration of leptin positive and leptin-receptor positive cells}

Slides were incubated with a rabbit-polyclonal antibody $\mathrm{Ob}$ anti-leptin (A-20; 1:20 dilution; $1 \mathrm{~h}$ at room temperature), and with a goat-polyclonal antibody $\mathrm{Ob}-\mathrm{R}$ anti-leptin receptor (M18; $1: 15$ dilution; overnight; $\left.4^{\circ} \mathrm{C}\right)$. Both antibodies were from Santa Cruz Biotechnology (Santa Cruz, CA, USA) [21]. The reaction was revealed by labelled streptovidin-biotinkit-horseradish peroxidase (LSAB+KIT-HRP; DAKO, Glostrup, Denmark), according to the manufacturers instructions. Control slides for leptin were prepared as described by CAMPBell et al. [22]. The immunocomplex was obtained by immunoprecipitation (A/G plus-agarose; Santa Cruz Biotechnology), and by incubation with the rabbit-polyclonal antibody $\mathrm{Ob}\left(2 \mu \mathrm{g} \cdot \mathrm{mL}^{-1}\right)$ and human recombinant leptin $\left(20 \mu \mathrm{g} \cdot \mathrm{mL}^{-1}\right.$; Sigma Aldrich) overnight at $4^{\circ} \mathrm{C}$. Control slides for the leptin-receptor were prepared using the antibody diluent. The cell nuclei were stained for $1 \mathrm{~min}$ with haematoxylin (DAKO). Slides were evaluated using a Leica (Wetzlar, Germany) microscope at $\times 400$ magnification. In the submucosa, positive cells were counted along the entire length of the epithelial basement per unit area $\left(\mathrm{mm}^{2}\right)$. In the epithelium, positive cells were evaluated per area over a minimum length of $260 \mu \mathrm{m}$ from the internal side of the epithelium. The images were then subsequently analysed using a Quantimet $500 \mathrm{MC}$ software (Leica) for image analysis.

\section{Enumeration of inflammatory cells}

Neutrophils, activated T-lymphocytes (CD45R0), CD8+ T cells and macrophages were characterised using the following monoclonal antibodies: 1) anti-neutrophil elastase (Clone NP57 diluted 1:5; incubated overnight at $\left.4{ }^{\circ} \mathrm{C}\right)$; 2) anti-T cell CD45R0 (Clone UCHL-1 diluted 1:50; incubated $1 \mathrm{~h}$ at room temperature); 3) anti-CD8 $\mathrm{T}$ cell (Clone C8/144B diluted 1:10; incubated overnight at $4^{\circ} \mathrm{C}$ ); and 4) anti-CD68 (Clone KP1 diluted 1:50; incubated overnight at $4^{\circ} \mathrm{C}$ ). All antibodies were from DAKO. To expose the immunoreactive epitopes of cell markers the slides stained for CD45R0, CD68 and elastase were pre-incubated with $0.1 \%$ trypsin in trizma buffer saline, $\mathrm{pH} 7.6$ at $37^{\circ} \mathrm{C}$ for $10 \mathrm{~min}$, while the sections to be stained for CD8+ T cells were pre-treated in trizma buffer saline, $\mathrm{pH} 9.1$ and incubated at $92^{\circ} \mathrm{C}$ for $45 \mathrm{~min}$.

\section{Enumeration of inflammatory cells expressing leptin and leptin-receptor}

To assess the expression of leptin and leptin-receptor by neutrophils, macrophages, CD45R0 and CD8+ T cells, a double immunostaining was performed. This combined the LSAB+ KIT-HRP technique used to identify cells expressing leptin and its receptor, with the alkaline phosphatase antialkaline phosphatase (DAKO) technique used to identify cell phenotypes [23].

\section{Enumeration of apoptosis in leptin positive and leptin- receptor positive cells}

The co-localisation of leptin or leptin-receptor with apoptotic cells was studied by combining the alkaline phosphatase terminal deoxynucleotidyl transferase dUTP-mediated nick end labelling (TUNEL) technique (Roche Diagnostic $\mathrm{GmbH}$, Indianapolis, IN, USA) [23], used to identify apoptotic cells (nuclear staining), with the DAKO LSAB+KIT-HRP technique, used to identify the leptin and leptin-receptor (cytoplasmic staining).

\section{Enumeration of apoptosis in CD45R0 and CD8+T cells}

Apoptosis was also studied in CD45R0 and in CD8+ T cells by combining the peroxidase TUNEL technique (Roche Diagnostic GmbH) [20], used to identify apoptotic cells 
TABLE 1 Demographic characteristics of the patients

\begin{tabular}{|c|c|c|c|c|c|c|}
\hline Age yrs & 25 (23-31) & $26(20-50)$ & $57(45-69)$ & NS & $<0.0003$ & $<0.005$ \\
\hline Sex M:F ratio & 61.5 & 81 & 88 & NA & NA & NA \\
\hline FEV $1 \%$ pred & $106(96-122)$ & $100(91-102)$ & $60(48-78)$ & NS & $<0.0007$ & $<0.001$ \\
\hline
\end{tabular}

Data are presented as median (25-75 percentiles), $\mathrm{n}$ or \%, unless otherwise stated. GOLD: Global initiative for Chronic Obstructive Lung Disease; COPD: chronic obstructive pulmonary disease; M: male; F: female; FEV1 pred: forced expiratory volume in one second predicted; FVC: forced vital capacity; NA: not applicable; NS: nonsignificant.

TABLE 2 Leptin and leptin-receptors in the epithelial cells

\begin{tabular}{|c|c|c|c|c|c|c|}
\hline & $\begin{array}{l}\text { Normal } \\
\text { subjects }\end{array}$ & $\begin{array}{l}\text { Smokers } \\
\text { (GOLD 0) }\end{array}$ & $\begin{array}{l}\text { Mild-to-severe COPD } \\
\quad(\text { GOLD 1-3) }\end{array}$ & $\begin{array}{c}\text { p-value controls } \\
\text { GOLD } 0\end{array}$ & $\begin{array}{l}\text { p-value controls } \\
\text { GOLD 1-3 }\end{array}$ & $\begin{array}{l}\text { p-value GOLD } 0 \\
\text { GOLD 1-3 }\end{array}$ \\
\hline Leptin receptor+cells & $39(34-40)$ & $16(11-33)$ & $24(16-28)$ & $<0.04$ & $<0.02$ & NS \\
\hline
\end{tabular}

Data presented as median (25-75 percentiles). GOLD: Global initiative for Chronic Obstructive Lung Disease; COPD: chronic obstructive pulmonary disease; NS: nonsignificant.

(nuclear staining), with the DAKO LSAB2 alkaline phosphatase method, used to identify the inflammatory cells (cytoplasmic staining).

\section{Statistical analysis}

Data are expressed as median (25-75 percentiles). A Kruskal Wallis test was performed for comparison among the three groups of subjects in addition with post hoc Bonferroni-Dunn tests. A nonparametric Mann-Whitney U-test was applied between two groups when the initial Kruskal Wallis was significant. Correlations were determined using a Spearman rank correlation or a Kendall tau test. Differences were considered significant if $\mathrm{p}<0.05$.

\section{RESULTS}

\section{Demographic characteristics of the patients}

Demographic characteristics of the patients are reported in table 1. By comparison to the other two groups, COPD patients with mild-to-severe disease (GOLD 1-3) had a significantly lower FEV1 and FEV1/forced vital capacity (FVC) levels. Moreover, they had smoked significantly more than smokers at risk for COPD (GOLD 0). There was a significant correlation between the smoking consumption and FEV1 $(p<0.003$, Spearman rank correlation), FEV1/FVC $(\mathrm{p}<0.0009)$ and GOLD stage $(p<0.002$, Kendall's $\tau$ au test $)$.

\section{Enumeration of leptin and leptin-receptor}

In the epithelial cells, the expression of leptin and its receptors was higher in normal subjects than in smokers or in mild-tosevere COPD subjects (table 2; fig. 1). In the sub-mucosa, the expression of leptin was significantly higher in COPD than in smokers and normal subjects. Conversely, the expression of leptin-receptors was similar in the three studied groups (table 3; fig. 1).


FIGURE 1. Leptin positive biopsies of a) normal and b) chronic obstructive pulmonary disease (COPD) subjects. Leptin-receptor positive biopsies of c) norma and d) COPD subjects (see material and methods for details). Scale bar $=40 \mu \mathrm{m}$. 
TABLE 3 Submucosal infiltrate

\begin{tabular}{|c|c|c|c|c|c|c|}
\hline CD8+ positive cells & $0(0-0)$ & $17(12-22)$ & $25(15-43)$ & $<0.0001$ & $<0.0001$ & $<0.02$ \\
\hline CD45R0 positive cells & $44(41-54)$ & $57(25-70)$ & $120(97-159)$ & NS & $<0.0002$ & $<0.0002$ \\
\hline Neutrophils & $0(0-2)$ & $0.5(0-5)$ & $0.2(0-4)$ & NS & NS & NS \\
\hline
\end{tabular}

Data are presented as median (25-75 percentiles). GOLD: Global initiative for Chronic Obstructive Lung Disease; COPD: chronic obstructive pulmonary disease; Ns: nonsignificant.

TABLE 4 Results of double-immunostaining

\begin{tabular}{|c|c|c|c|c|c|c|}
\hline & $\begin{array}{l}\text { Normal } \\
\text { subjects }\end{array}$ & $\begin{array}{l}\text { Smokers } \\
\text { (GOLD 0) }\end{array}$ & $\begin{array}{l}\text { Mild-severe COPD } \\
\text { (GOLD 1-3) }\end{array}$ & $\begin{array}{l}\text { p-value controls } \\
\text { GOLD } 0\end{array}$ & $\begin{array}{l}\text { p-value controls } \\
\text { GOLD 1-3 }\end{array}$ & $\begin{array}{l}\text { p-value GOLD } 0 \\
\text { GOLD 1-3 }\end{array}$ \\
\hline CD8+/Leptin receptor+ & NA & $47(44-48)$ & $67(47-92)$ & NA & NA & $<0.0003$ \\
\hline CD8+/TUNEL+ & NA & $16(13-20)$ & $0(0-5)$ & NA & NA & $<0.0001$ \\
\hline CD45R0/Leptin + & $0(0-10)$ & $42(17-52)$ & $90(85-90)$ & $<0.0001$ & $<0.0001$ & $<0.0001$ \\
\hline
\end{tabular}

Data are presented as median (25-75 percentiles of percentages of total CD45R0 or CD8 ${ }^{+}$cells). GOLD: Global Initiative of Chronic Obstructive Lung Disease; COPD chronic obstructive pulmonary disease: TUNEL: terminal deoxynucleotidyl transferase dUTP nick end-labelling; NA: not available.

\section{Enumeration of inflammatory infiltrate}

In the sub-mucosa, the number of macrophages (CD68 positive cells) and the number of CD45R0 and CD8+ T cells were significantly higher in mild-to-severe COPD subjects than in smokers or in normal subjects, while the number of neutrophils (elastase positive cells) was similar in the three groups (table 3).

\section{Co-localisation of leptin and leptin-receptor in inflammatory cells}

In COPD patients and smokers, most of the cells expressing leptin and leptin-receptors were CD45R0 and CD8+ T cells (table 4; fig. 2) whereas few neutrophils and macrophages were found to be positive for these markers. In addition, in COPD subjects, the percentage of CD45R0 and CD8+ T cells expressing leptin and its receptor was greater than in smokers (table 4). In normal subjects few CD45R0 $\mathrm{T}$ cells were found to be positive for leptin and its receptor (table 4), whereas there were no CD8+ T cells, neutrophils and macrophages the colocalisation analysis was not possible.

\section{Enumeration of apoptotic CD45RO and $C D 8^{+} T$ cells}

In the biopsies obtained from normal subjects, the absence of a sufficient number of lymphocytes precluded the performance of any apoptosis assay. In COPD patients, no apoptotic CD45R0 or CD8+ T cells were found (fig. 3). In contrast, in smokers there were a low percentage of apoptotic CD45R0 T cells (median percentage of apoptotic over total $=8 \%$; $25-75$
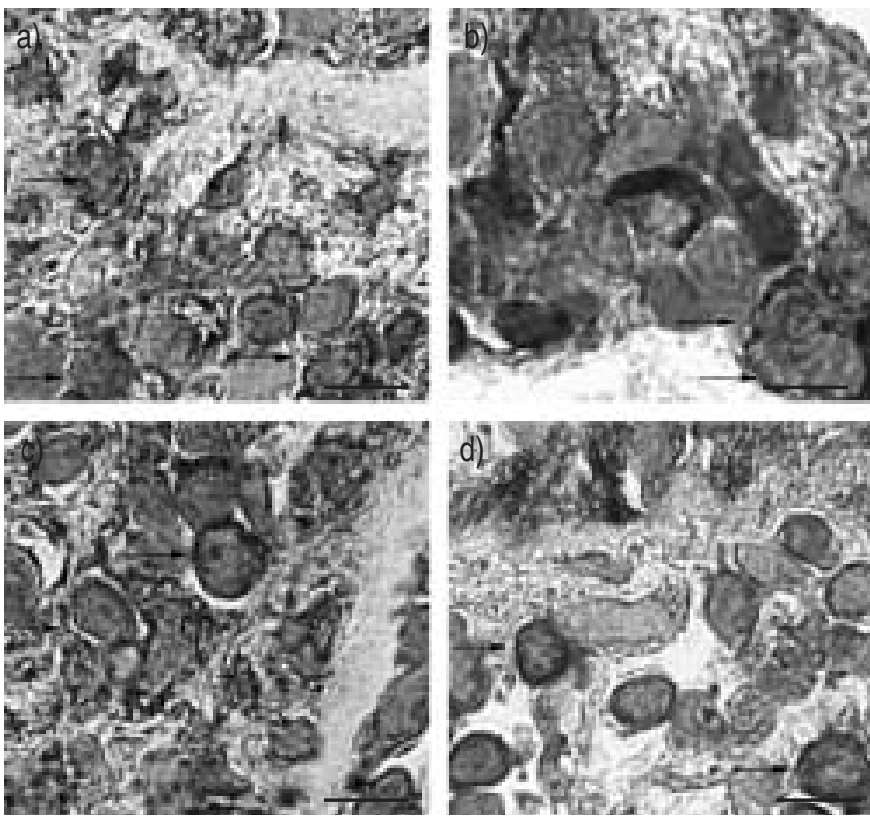

FIGURE 2. Leptin and its receptor are expressed by CD45R0 and by $\mathrm{CD}^{+} \mathrm{T}$ cells in chronic obstructive pulmonary disease (COPD). Double stained cells show a co-localised immunoreactivity. Leptin expression by a) CD45R0 and b) $C D 8^{+} \mathrm{T}$ cells. Leptin receptor expression by c) CD45R0 and d) $C D 8^{+} \mathrm{T}$ cells. Arrows indicate the double stained cells (see material and methods for details). Scale bar $=18 \mu \mathrm{m}$. 

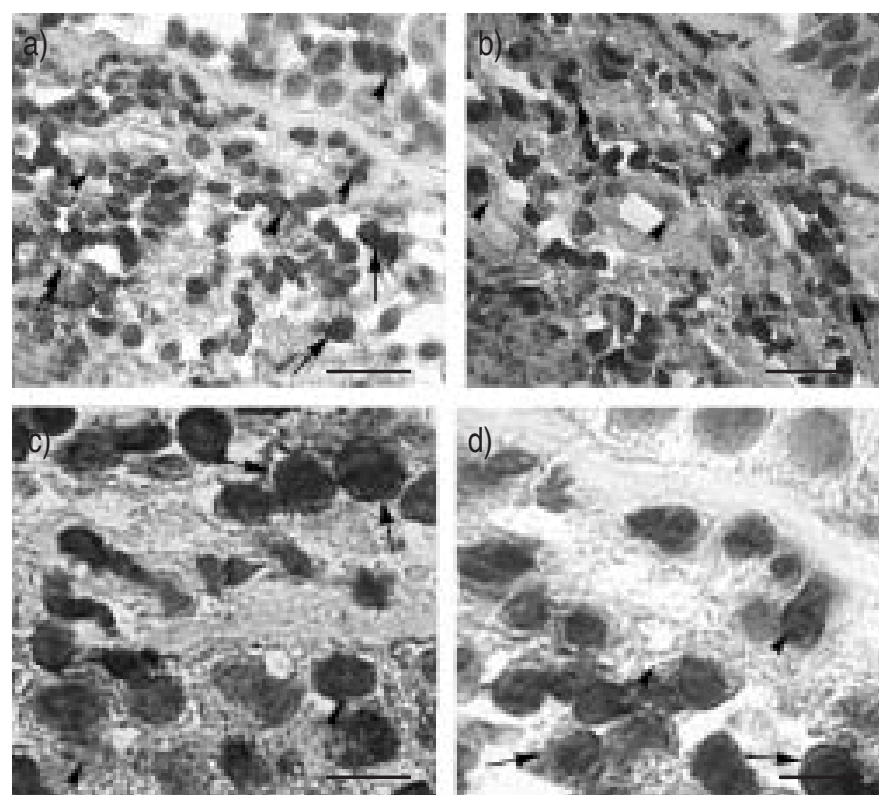

FIGURE 3. CD45RO positive cells $(a, c)$ and $C D 8^{+} T$ cells $(b, d)$ are not apoptotic in chronic obstructive pulmonary disease patients. The identification of apoptosis was given by nuclear staining while the identification of CD45R0 and $\mathrm{CD}^{+} \mathrm{T}$ cells was given by cytoplasmic staining. Arrows indicate CD45R0 and $\mathrm{CD}^{+} \mathrm{T}$ cells. Arrowheads indicate apoptotic cells a, b) Scale bar $=40 \mu \mathrm{m}$, c, d) scale bar $=18 \mu \mathrm{m}$

percentile $=6.7-9.6$ ) and of apoptotic CD8 $+\mathrm{T}$ cells (median percentage of apoptotic over total $=18 \% ; 25-75$ percentile $=3.5-$ 20).

\section{Enumeration of apoptotic leptin positive and leptin-receptor positive cells}

The combination of the TUNEL technique with immunohistochemistry for leptin and leptin-receptor showed that, in COPD patients and in smokers, none of the cells expressing leptin and/or leptin-receptors were apoptotic (fig. 4).

\section{Correlation between leptin positive and leptin-receptor positive cells and clinical and functional parameters}

Leptin positive cells negatively correlated with both FEV1 and FEV1/FCV values $(p<0.01$ and $p<0.006$, respectively, Spearman rank correlation) and GOLD stages $(\mathrm{p}<0.0001$; Kendall's cau test: 0.57 ; fig 5). With the exception of one patient, a relevant number of leptin positive cells were present in only patients with FEV1 $<80 \%$ predicted. There was no significant correlation between smoking consumption and leptin positive cells. GOLD stages were significantly associated with CD45R0 apoptotic cells $(p<0.02$, Kendall's tau test correlation) and CD8+ T apoptotic cells $(\mathrm{p}<0.01)$.

\section{DISCUSSION}

The present study demonstrated that in the submucosa, the expression of leptin is significantly higher in COPD than in smokers and normal subjects. In epithelial cells, the expression of leptin and its receptors is higher in normal subjects than in smokers or in mild-to-severe COPD patients. Leptin plays a role in the regulation of food intake and energy expenditure
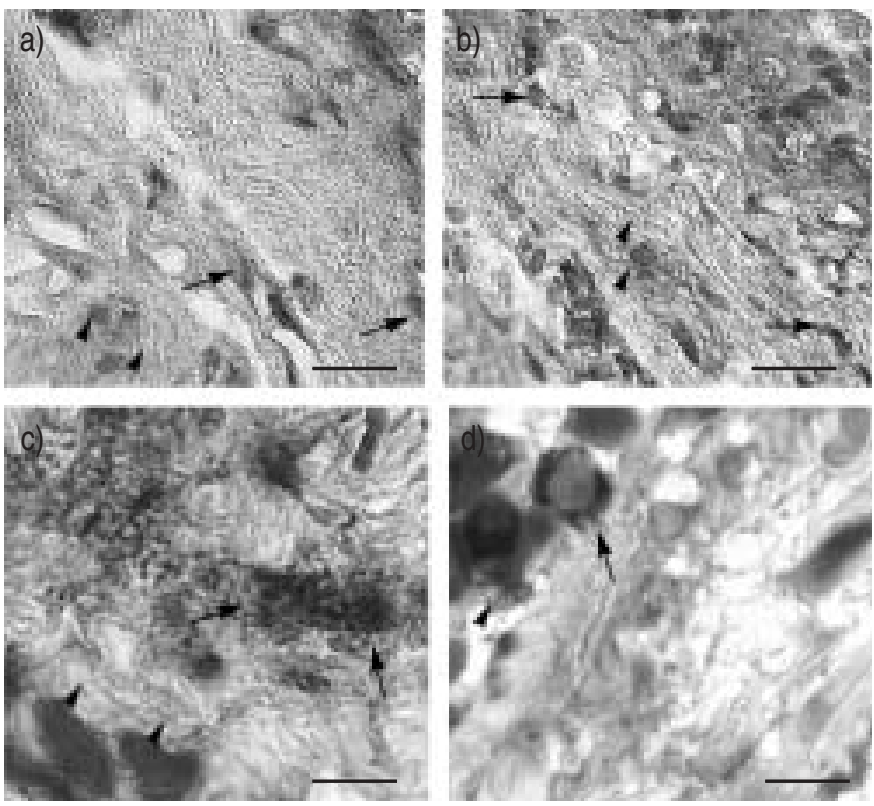

FIGURE 4. Leptin positive cells ( $a, c)$ and leptin receptor positive cells (b, d) are not apoptotic in chronic obstructive pulmonary disease patients. The identification of apoptosis was given by nuclear staining while the identification of leptin and its receptor-positive cells was given by cytoplasmic staining. Arrows indicate leptin and its receptor-positive cells. Arrowheads indicate apoptotic cells. a, b) Scale bar $=40 \mu \mathrm{m}, \mathrm{c}, \mathrm{d})$ scale bar $=18 \mu \mathrm{m}$.

and appears to act as a link between immune and endocrine functions [6, 7, 24-28]. The present study is the first investigating the leptin and leptin-receptor expression in the bronchial tissue of smokers with or without COPD. Previous findings have shown a relationship between leptin release in patients with COPD and wasting [16, 17]. A pleiotropic role for leptin in mammalian physiology has been suggested, this being leptin-deficient mice characterised not only by obesity, but also by abnormalities in reproductive function, hormone levels, wound repair, bone structure, and immune function [13, 27]. Based upon this evidence, and on leptin and

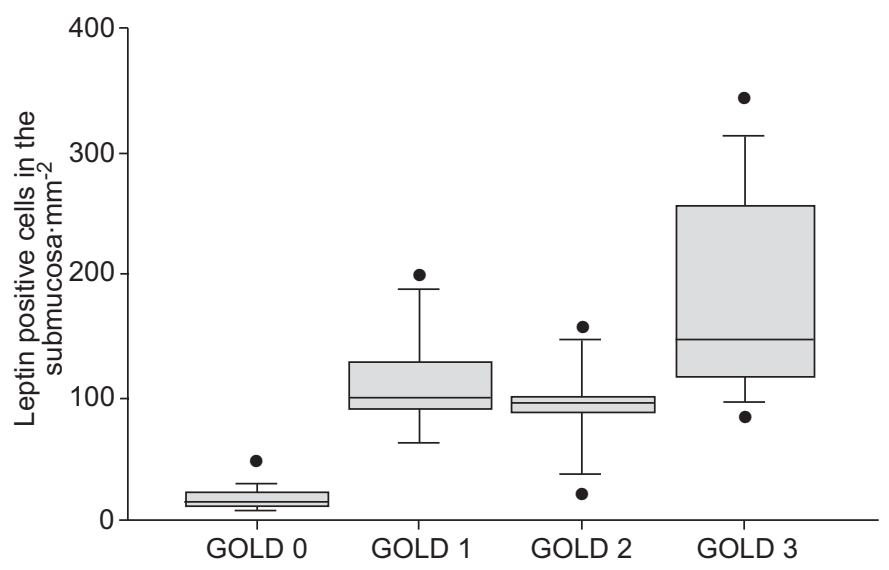

FIGURE 5. Leptin positive cells are directly correlated with Global Initiative of Chronic Obstructive Lung Disease (GOLD) stages. Gold 0: $n=15$; Gold 1: $n=11$; Gold 2: $n=7$; Gold 3: $n=9$. Kendall rau test: 0.57; $p<0.0001$. 
leptin-receptor structure, the concept that leptin may function as an immunomodulatory cytokine has been increasingly accepted [6,7]. Leptin can also modulate the function of $\mathrm{T}$ lymphocytes, being able to enhance T-cells proliferative response and cytokines production by $\mathrm{T}$ lymphocytes. Also of great interest is the finding that leptin can polarise Th cells toward a Th1 phenotype [28], and can modulate cell survival by inhibiting apoptosis [11], suggesting that leptin regulates important aspects of immunity by regulating the survival of $\mathrm{T}$ lymphocytes.

It has also been demonstrated that leptin has a proliferative and anti-apoptotic role for intraepithelial CD8+ T lymphocytes in colitis in wild type mice versus ob/ob mice [29]. In keeping with the aforementioned concepts, in the present study it was demonstrated that in COPD there is an overexpression of leptin in the sub-mucosa correlated to the expression of the lymphocytes $\mathrm{T}$ activated, mainly CD8+ $\mathrm{T}$ lymphocytes. Besides, none of the inflammatory cells are apoptotic and none of the cells expressing leptin and/or leptin-receptor are apoptotic. In contrast, in the sub-mucosa of smokers with normal lung function the expression of leptin and its receptor is lower than in the sub-mucosa of COPD, as well as the expression of inflammatory cells, some of which are apoptotic. These findings suggest that in COPD the expression of leptin and its receptor can regulate proximal airway inflammation. Furthermore, a significant correlation was found between leptin and the severity of COPD, suggesting that leptin over-expression may have an impact on both mucosal inflammation and disease status. Therefore, the current results suggest that in bronchial sub-mucosa leptin may act within the bronchial wall as a potential mediator able to perpetuate bronchial inflammation by increasing the survival of some inflammatory cells. Compelling evidence has shown a rich inflammatory cellular network infiltrating the airways of COPD that significantly correlates with airflow limitation [30,31]. However, since the COPD patients were older than the control subjects (smokers or nonsmokers), it is unlikely that this difference might have influenced the proximal airway inflammation despite some data obtained in rodents showing an increase in CD45R0 cells with ageing [32]. The contribution of proximal airways to COPD was associated with the chronic bronchitis phenotype. In the present study few patients complained of chronic cough and sputum production, a situation which did not allow examination of the potential relationships with leptin expression. In COPD, CD8+ T lymphocytes are thought to act as effectors of the cell-mediated immune response, representing the anti-viral arm of the immunological system. In the present study, no apoptotic CD8+ cells could be found in COPD patients while a low percentage (median: $3 \%$ ) of apoptotic CD8+ cells was detected in smokers. These findings, together with the finding that leptin, a well established antiapoptotic mediator [6, 9, 11], was over-expressed in COPD patients suggest a probable role of leptin in the regulation of CD8+ cell apoptosis in COPD. Leptin may affect other lymphocytes as shown by the high number of CD45R0 cells being positive for leptin and nonapoptotic. CD4 lymphocytes are potential key players in COPD, but their role remained to be fully demonstrated. Conversley, albeit of potential importance, few neutrophils and airway macrophages were positive for leptin. Neutrophils are mainly found in the lumen of the bronchi in COPD. Macrophages can be regulated by leptin, but they are not able to produce leptin to the best of the current knowledge [33]. Leptin has been associated with bacterial pulmonary infection, a condition which could induce COPD exacerbations. The over-expression of leptin in inflammatory cells within the submucosa of the bronchi in COPD might be related to the recurrence of infections in that condition. Apoptosis helps to maintain constant cell numbers and its deregulation causes pathological conditions such as inflammation and cancer, due to the activation of antiapoptotic Bcl-2 family members (e.g. Bcl-2 and Bcl-xl) [34]. A Previous study shows the ability of leptin to upregulate $\mathrm{Bcl}-\mathrm{xl}$ through the leptin receptor on lymphocytes [11]. In this context leptin may contribute with its anti-apoptotic activity to the accumulation of $\mathrm{T}$ lymphocytes in the bronchial submucosa of COPD patients. In smokers without airflow obstruction, the lower expression of leptin may allow those cells to become apoptotic more frequently and then to be removed from the airways. The importance of the apoptosis rate to maintain the airways with a low inflammatory number has not been yet investigated. In the epithelial cells, and in very few inflammatory cells infiltrated within the epithelial layer in COPD, the expression of leptin and its receptor observed in the present study deserves some considerations. The increased immunoreactivity of leptin and its receptor in normal subjects in comparison with smokers and COPD patients may reflect different patterns of maturation and differentiation in the bronchial epithelium among the studied groups. As previously studied in animal models [35], the pathway of leptin and its receptor may be important in regulating the maturation of epithelial cells of the foetal lung as human gastric epithelium expresses leptin mRNA and leptin protein [36]. Epithelium abnormalities are hallmarks in the bronchi of smokers and COPD subjects [37]. The higher expression of leptin and its receptor in epithelial cells of the normal subjects rather than in modified epithelium of smokers and COPD subjects suggest that the leptin/leptinreceptor pathway is involved in the correct proliferation of the epithelial cells, and the decrease of leptin and its receptor expression in these two groups of subjects might be related to the ongoing epithelial changes demonstrated in these conditions. The exact contribution of leptin in those epithelial abnormalities deserves further investigation. A different pattern of expression of leptin and leptin receptors in the bronchi of normal subjects was observed in patients at risk for COPD (GOLD 0) and patients with COPD with airflow impairment. Leptin positive cells inversely correlated with the FEV1 and with the FEV1/FVC values in COPD subjects (GOLD 0-3), demonstrating that the pro-inflammatory role played by leptin is also associated with a progressive functional impairment. This evidence may support the hypothesis that leptin can play a cytokine-like role within the airways and mainly regulates the inflammatory cell infiltration of the submucosa in COPD. Several cytokines, including IL-4 and IL-13, have been shown to act as potential pro-inflammatory mediators in the bronchi of COPD patients [38]. Some other cytokines involved in the COPD inflammation, such as IL- 6 and tumour necrosis factor- $\alpha$, have been shown to regulate leptin in several models [39]. Leptin influences innate and adaptive immune responses as well as 
autoimmunity [2]. White adipose tissue is now recognised to be a multifunctional organ, by the production of different adipokines involved in inflammation which can influence inflammatory process at different levels [40].

In this context, leptin represents a pleiotropic molecule together with the other adipokines involved in the regulation of the immune system. In this scenario it is conceivable that leptin might act as a cytokine-like mediator capable of playing a role in airway inflammation in chronic obstructive pulmonary disease with a potential impact on the severity of the disease.

\section{REFERENCES}

1 Celli BR, MacNee W, ATS/ERS Task Force. Standards for the diagnosis and treatment of patients with COPD: a summary of the ATS/ERS position paper. Eur Respir J 2004; 23: 932-946.

2 La Cava A, Matarese G. The weight of leptin in immunity. Nat Rev Immunol 2004; 4: 371-379.

3 Mix H, Widjaja A, Jandl O, et al. Expression of leptin and leptin receptor isoforms in the human stomach. Gut 2000; 47: 481-486.

4 Barrenetxe J, Villaro AC, Guembe L, et al. Distribution of the long leptin receptor isoform in brush border, basolateral membrane, and cytoplasm of enterocytes. Gut 2002; 50: 797-802.

5 Ur E, Wilkinson DA, Morash BA, Wilkinson M. Leptin immunoreactivity is localized to neurons in rat brain. Neuroendocrinology 2002; 75: 264-272.

6 Fantuzzi G, Faggioni R. Leptin in the regulation of immunity, inflammation, and haematopoiesis. I Leukoc Biol 2000; 68: 437-446.

7 Faggioni R, Feingold KR, Grunfeld C. Leptin regulation of the immune response and the immunodeficiency of malnutrition. Faseb J 2001; 15: 2565-2571.

8 Goldberg AC, Eliaschewitz FG, Montor WR, et al. Exogenous leptin restores in vitro $\mathrm{T}$ cell proliferation and cytokine synthesis in patients with common variable immunodeficiency syndrome. Clin Immunol 2005; 114: 147-153.

9 Najib S, Sanchez-Margalet V. Human leptin promotes survival of human circulating blood monocytes prone to apoptosis by activation of p42/44 MAPK pathway. Cell Immunol 2002; 220: 143-149.

10 Laharrague $\mathrm{P}$, Oppert JM, Brousset $\mathrm{P}$, et al. High concentration of leptin stimulates myeloid differentiation from human bone marrow CD34+ progenitors: potential involvement in leukocytosis of obese subjects. Int J Obes Relat Metab Disord 2000; 24: 1212-1216.

11 Fujita $\mathrm{Y}$, Murakami M, Ogawa $\mathrm{Y}$, et al. Leptin inhibits stress-induced apoptosis of $\mathrm{T}$ lymphocytes. Clin Exp Immunol 2002; 128: 21-26.

12 Santos-Alvarez J, Goberna R, Sanchez-Margalet V. Human leptin stimulates proliferation and activation of human circulating monocytes. Cell Immunol 1999; 194: 6-11.

13 Marikovsky M, Rosenblum CI, Faltin Z, Friedman-Einat M. Appearance of leptin in wound fluid as a response to injury. Wound Repair Regen 2002; 10: 302-307.
14 Suganami E, Takagi $\mathrm{H}$, Ohashi $\mathrm{H}$, et al. Leptin stimulates ischemia-induced retinal neovascularization: possible role of vascular endothelial growth factor expressed in retinal endothelial cells. Diabetes 2004; 53: 2443-2448.

15 Sweeney G. Leptin signalling. Cell Signal 2002; 14: 655-663.

16 Schols AM, Creutzberg EC, Buurman WA, Campfield LA, Saris WH, Wouters EF. Plasma leptin is related to proinflammatory status and dietary intake in patients with chronic obstructive pulmonary disease. Am J Respir Crit Care Med 1999; 160: 1220-1226.

17 Creutzberg EC, Wouters EF, Vanderhoven-Augustin IM, Dentener MA, Schols AM. Disturbances in leptin metabolism are related to energy imbalance during acute exacerbations of chronic obstructive pulmonary disease. Am J Respir Crit Care Med 2000; 162: 1239-1245.

18 Fabbri LM, Romagnoli M, Corbetta L, et al. Differences in airway inflammation in patients with fixed airflow obstruction due to asthma or chronic obstructive pulmonary disease. Am J Respir Crit Care Med 2003; 167: 418-424.

19 Pauwels RA, Buist AS, Calverley PM, Jenkins CR, Hurd SS. Global strategy for the diagnosis, management, and prevention of chronic obstructive pulmonary disease. NHLBI/WHO Global Initiative for Chronic Obstructive Lung Disease (GOLD) Workshop summary. Am J Respir Crit Care Med 2001; 163: 1256-1276.

20 Vignola AM, Chanez P, Chiappara G, et al. Evaluation of apoptosis of eosinophils, macrophages, and T lymphocytes in mucosal biopsy specimens of patients with asthma and chronic bronchitis. J Allergy Clin Immunol 1999; 103: 563-573.

21 De Matteis R, Dashtipour K, Ognibene A, Cinti S. Localization of leptin receptor splice variants in mouse peripheral tissues by immunohistochemistry. Proceedings of the Nutrition Society 1998; 57: 441-448.

22 Campbell AM, Vachier I, Chanez P, et al. Expression of the high-affinity receptor for $\operatorname{IgE}$ on bronchial epithelial cells of asthmatics. Am J Respir Cell Mol Biol 1998; 19: 9297.

23 Bonkhoff $H$, Fixemer T, Hunsicker I, Remberger K. Simultaneous detection of DNA fragmentation (apoptosis), cell proliferation (MIB-1), and phenotype markers in routinely processed tissue sections. Virchows Arch 1999; 434: 71-73.

24 Prolo P, Wong ML, Licinio J. Leptin. Int J Biochem Cell Biol 1998; 30: 1285-1290.

25 Sanchez-Margalet V, Martin-Romero C, Santos-Alvarez J, Goberna R, Najib S, Gonzalez-Yanes C. Role of leptin as an immunomodulator of blood mononuclear cells: mechanisms of action. Clin Exp Immunol 2003; 133: 11-19.

26 Ozata M, Ozdemir IC, Licinio J. Human leptin deficiency caused by a missense mutation: multiple endocrine defects, decreased sympathetic tone, and immune system dysfunction indicate new targets for leptin action, greater central than peripheral resistance to the effects of leptin, and spontaneous correction of leptin-mediated defects. Clin Endocrinol Metab 1999; 84: 3686-3695.

27 Stepanovic V, Awad O, Jiao C, Dunnwald M, Schatteman GC. Leprdb diabetic mouse bone marrow cells inhibit skin wound vascularization but promote wound healing. Circ Res 2003; 92: 1247-1253. 
28 Lord GM, Matarese G, Howard JK, Baker RJ, Bloom SR, Lechler RI. Leptin modulates the T-cell immune response and reverses starvation-induced immunosuppression. Nature 1998; 394: 897-901.

29 Siegmund B, Lehr HA, Fantuzzi G. Leptin: a pivotal mediator of intestinal inflammation in mice. Gastroenterology 2002; 122: 2011-2025.

30 Baraldo S, Turato G, Badin C, et al. Neutrophilic infiltration within the airway smooth muscle in patients with COPD. Thorax 2004; 59: 308-312.

31 Turato G, Zuin R, Miniati M, et al. Airway inflammation in severe chronic obstructive pulmonary disease: relationship with lung function and radiologic emphysema. Am J Respir Crit Care Med 2002; 166: 105-110.

32 Ishimoto Y, Tomiyama-Miyaji C, Watanabe H, et al. Agedependent variation in the proportion and number of intestinal lymphocyte subsets, especially natural killer $\mathrm{T}$ cells, double-positive CD4+ CD8+ cells and B220+ T cells, in mice. Immunology 2004; 113: 371-377.

33 Lazar MA. How obesity causes diabetes: not a tall tale. Science 2005; 307: 373-375.
34 Yousefi S, Conus S, Simon HU. Cross-talk between death and survival pathways. Cell Death and Differentiation 2003; 10: 861-863.

35 Bergen HT, Cherlet TC, Manuel P, Scott JE. Identification of leptin receptors in lung and isolated fetal type II cells. Am J Respir Cell Mol Biol 2002; 27: 71-77.

36 Cinti S, Matteis RD, Pico C, et al. Secretory granules of endocrine and chief cells of human stomach mucosa contain leptin. Int J Obes Relat Metab Disord 2000; 24: 789-793.

37 Vachier I, Vignola AM, Chiappara G, et al. Inflammatory features of nasal mucosa in smokers with and without COPD. Thorax 2004; 59: 303-307.

38 Miotto D, Ruggieri MP, Boschetto P, et al. Interleukin-13 and -4 expression in the central airways of smokers with chronic bronchitis. Eur Respir J 2003; 22: 602-608.

39 Coppack SW. Pro-inflammatory cytokines and adipose tissue. Proc Nutr Soc 2001; 60: 349-356.

40 Trayhurn P, Wood IS. Adipokines: inflammation and the pleiotropic role of white adipose tissue. Br J Nutr 2004; 92: 347-355. 